\title{
In the Factory, in Łódź, in the City. Reconstructing the Industrial Past of a Place
}

\section{Łódź - Industrial Heritage}

Łódź is a place created for industry and by industry - a suggestive exemplification of intense urbanisation and industrialisation processes from the second half of the $19^{\text {th }}$ century and the beginning of the $20^{\text {th }}$ century. Industrial plants were important elements in the layout of Łódź, frequently influencing the size and form of quarters and determining the arrangement of streets. They were located along the two main rivers flowing westward: the Jasien and the Łódka, and in the city centre - also within the frontage line - among residential buildings. The specific character of Łódź is constituted by the fact that two worlds - the world of work and the world of private life of both workers and employers - were adjacent to one another and merged. Moreover, factories used to be the most monumental structures in the city, while factory and residential complexes were among few well-thought-out urban development concepts. The industrial landscape of Łódź is a perfect example of styles and trends in the art of the second half of the $19^{\text {th }}$ century and the beginning of the $2 \mathrm{O}^{\text {th }}$ century. It also proves that Łódź was influenced by the main artistic centres of Central Europe (such as Berlin, Saint Petersburg and Vienna) (cf. Stefański 2or6).

This legacy, particularly after the collapse of many industrial cities at the beginning of the I990s, was not seen as capital that could form a basis for the identity of a modern metropolis or an image of a city attractive to tourism and investments. However, urban masters - decision-makers and citizens of Łódź 
- just in time noted trends connected with revival of post-industrial cities and the potential of revitalisation programmes ${ }^{\mathrm{I}}$.

This gave rise to the image of Łódź as a creative city, heavily relying on its industrial past and unique territorial capital. This strategy is undoubtedly supported by the growing significance and potential of the industrial heritage. Let us have a closer look at its definition. According to TICCIH (The International Committee for the Conservation of the Industrial Heritage), an organisation established in 1978 that deals with the industrial heritage, and in particular its promotion, preservation, protection, documentation, studying and interpretation, it consists of:

the remains of industrial culture that are of historical, technological, social, architectural and scientific value. These remains include buildings, machines, workshops, factories, mines with processing and clearing plants, storehouses and depots, plants producing, distributing and using electricity, transport and its whole infrastructure as well as places connected with the industry-related social activity, such as the housing industry, religious practices and education (Kronenberg 2009: 192).

Such heritage does not only include tangible objects, which is emphasised by the joint declaration of two international organisations: ICOMOS (International Council on Monuments and Sites) and TICCIH, adopted in Dublin in 20Ir:

Around the World, a great diversity of sites, structures, complexes, cities and settlements, areas, landscapes and routes bear witness to human activities of industrial extraction and production. In many places, this heritage is still in use and industrialisation is still an active process with a sense of historical continuity, while in other places it offers archaeological evidence of past activities and technologies. Besides the tangible heritage associated with industrial technology and processes, engineering, architecture and town-planning, it includes many intangible dimensions embodied in the skills, memories and social life of workers and their communities (Joint ICOMOS - TICCIH Principles for the Conservation of Industrial Heritage... 20II).

This intangible aspect of heritage offers us the sense of identity and belonging to a community, builds cultural continuity, and stimulates the development of the social capital together with important factors of economic development.

I In the paper, I do not analyse the notion of revitalisation (which is present in the discourses of history, geography, architecture, art history, economy, sociology, archaeology, and cultural anthropology), however, the subject itself indicates the issue of revitalisation practices. I will just emphasise that I understand revitalisation not only as a strategy for activities that repair, modernise and restore the existing infrastructure and boost the economy, but also as a set of cultural practices that have an effect on the creation of social relationships and the (re)construction of urban narratives. 
Today, the list of Łódź factories and, more generally, structures of industrial origin that have been converted includes more than a hundred projects of different scale, with different scopes of the changes introduced and varying quality of architectural solutions.

What is particularly important here is the use of post-industrial grounds, which are - according to the definition - unused, not fully used, or initially meant to be used by business activity that ended (Słodczyk 2003: 155-156), for new purposes connected with entrepreneurship and broadly defined culture, science, creativity and services.

One of such projects is MONOPOLIs, developed in the grounds of the former Monopol Wódczany in Łódź (Vodka Monopoly Plant in Łódź), later called Zakłady Przemysłu Spirytusowego 'Polmos' (Spirit Industry Factory 'Polmos'). The investor, Virako development company, is creating a modern office and service centre there. The aim of the investment is to thoroughly modernise and renovate the historical buildings of the former factory complex. In 20I4, at an early stage of the project, an idea emerged to conduct an interdisciplinary study into the past of this place. In 20I4-20I6, a team consisting of ethnologists, cultural anthropologists and archaeologists from the University of Łódź, implemented an ethnographic and archaeological research project Monopol Wódczany w Łodzi. Miejsce i ludzie (Vodka Monopoly Plant in Eódź. The Place and People).

The aim of our activities was mostly to collect oral histories and artefacts, which not only documented the history of Łódzkie Zakłady Przemysłu Spirytusowego 'Polmos', but also presented the professional biographies of Monopol's workers, meaning people whose lives had been intertwined with the activity of the plant. We believed that these 'small' stories would allow to recreate the 'great' story, the history of the former Monopol Wódczany, together with the related events.

Thus, we made an attempt at reconstruction, defining it as simply as possible, i.e. as recreation of something based on the preserved fragments, remains, and stories. A result of this attempt and the project was a publication Monopol Wódczany $w$ Eodzi. Miejsce opowiedziane / Vodka Monopoly Plant in Eódź. The Narrated Place (Karpińska, Krupa-Ławrynowicz, Ławrynowicz 2018).

2 The project was implemented by employees of the Institute of Ethnology and Cultural Anthropology of the University of Łódź (UŁ Professor, G.E. Karpińska, PhD;

A. Krupa-Ławrynowicz, PhD; UŁ Professor, A.P. Wejland, PhD) and the Institute of Archaeology of the University of Łódź (Olgierd Ławrynowicz, PhD) under a cooperation agreement between the Faculty of Philosophy and History of the University of Łódź and Virako Sp. z o.o. Students of Ethnology and Archaeology from the University of Łódź took part in the research. 


\section{A Very Brief History of the Place}

The foundation of a distillery in Łódź was closely related to the introduction of an alcohol monopoly in the territory of the Russian Empire, including Congress Poland, in the late $19^{\text {th }}$ century. This meant that the state had a monopoly on retailing spirit and vodka, and on manufacturing pure vodka. The reasons behind limiting competition were the protection of the fiscal interest of the state treasury and the state administration's attempt to control the supply of strong alcohol.

Another manifestation of the monopolistic policy was the launching of new investment and construction projects. In many places of the Russian Empire, storehouses and distilleries were built. Decisions about the construction of such industrial buildings were taken in the central offices of Saint Petersburg, which is why, in many cases, there are no details of their origins. For example, we have no information about the construction or the first years of operation of Monopol Wódczany, which appeared in the landscape of industrial Łódź, dominated by weaving plants, in $1902^{3}$. Monopoly in Łódź produced pure and flavoured vodkas, bottled spirit and methylated spirit.

The main factory building, modelled after spatial and functional solutions and architectural forms used in plants erected in large Russian cities at the time, was probably designed by Franciszek Chełmiński, who was a town planner known for designing many industrial buildings in Łódź. The whole factory complex consisted of an administration building, stables (later converted into garages), the main production building, a laboratory, and storehouses. A part of the plant was connected with a siding, and so, in functional terms, it was related to supply and dispatch. Some amenities were also built: a nursery, a canteen, and a three-storey residential building with a basement and a garden, the residents of which were higher administrative employees, i.e. department heads and directors (Fig. I).

The First World War was a very stormy and eventful period for the Łódź Monopol. When the German army seized the city, the factory was closed down, and the production of alcohol was stopped. In June 1916, Germans handed the buildings over to the municipal council, and they were adapted for new, public purposes. They housed a mortuary, a city school, a beggars' shelter, a shelter for families of soldiers killed in action, and grain storehouses. New walls and wall barriers were added. The equipment used for vodka production was confiscated by the invaders. Despite a number of modernisation investments made, such as

3 Information about the history of Monopol in Łódź comes from the study of B.M. Walczak (20I4) and materials gathered during field research and archive surveys. 


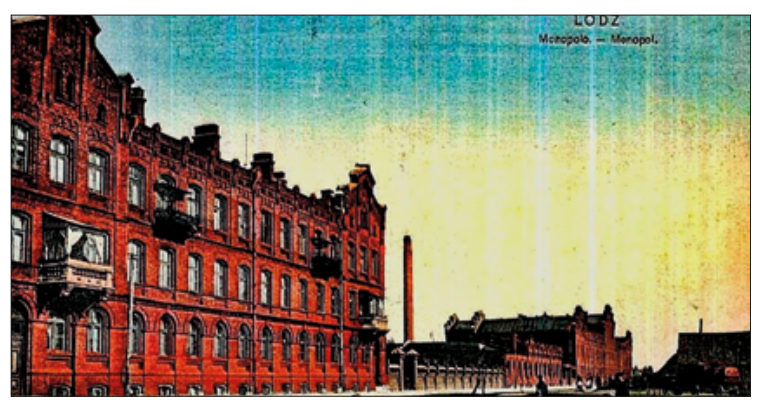

Fig. 1. Monopol from Zagajnikowa Street (today's S. Kopcińskiego Street); a coloured photograph from the first quarter of the $20^{\text {th }}$ century; as published on: Baedeker Łódzki (baedekerlodz.blogspot.com).

the digging of a well being the plant's own source of water, installation of central heating, and plumbing of a hot water system, most buildings could not be quickly restored to its pre-war condition to restart the production.

After the First World War, there were plans to use the former Monopoly as an excise inspectorate, however, they were never implemented. The property was taken over by the Treasury, which incorporated the plant into Państwowy Monopol Tytoniowy (State Tobacco Monopoly). In 1926, the production of tobacco products was moved, and in 1927, Państwowa Wytwórnia Wódek nr I4 (State Vodka Distillery no. 14) started operation in the factory, after some conversion work. It was a part of Państwowy Przemysł Spirytusowy (State Spirit Industry) in Warsaw.

The plant employed 300 people at the time, and a year later it had more than 600 workers. The plant was developing. In the 1930s, a clinic, a nursery, a library, a canteen, a workers' club, and a bathhouse were opened. Workers' children could go to health resort summer camps.

In 1939, after the Second World War started, most Polish workers were dismissed. One of the production floors was converted into a storehouse of food for the army, while the other was used for production limited to two bottling lines, but later it was also stopped. Production was only re-started in January 1945, after the city was liberated. Within a year, the factory reached its pre-war production volume.

After the war, the Łódź factory developed, with mergers with the production plant in Kutno and the industrial distillery in Sieradz. In 1963, the factory was renamed Łódzkie Zakłady Przemysłu Spirytusowego (Łódź Spirit Industry Factory), and in March 1973, based on a government decision, it was called Łódzkie Zakłady Przemysłu Spiritusowego 'Polmos' and became a part of a multi-facility Przedsiębiorstwo Przemysłu Spirytusowego 'Polmos' ('Polmos' Spirit Industry Company).

In 1960, a modernised department producing flavoured vodkas, sweet vodkas, and liqueurs was opened, and a year later, the first mechanised production lines in the Polish distilling industry appeared in the plant. This 
modernisation allowed to speed up the bottling process and to increase production capacity. Eight bottling lines, filling 70,000 bottles during an eighthour shift, were replaced with four bottling lines that could fill as many as I00,000 bottles. In 1967, the plant started exporting spirits to socialist countries, and to import raw materials for production. A clinic, a canteen, and a grocery kiosk were opened, and a recreation centre for workers and their children was built in Tworzyjanki.

In 1974, new Dutch production lines, the so-called Monoblocks, were installed, offering a capacity of 6,000 bottles per hour, and three years later new were added, with a capacity three times higher. Thanks to these and other efforts, monthly production volume of half a million 0.5 litre bottles of pure and flavoured vodkas was achieved. At the time, 620 people worked in the plant in two shift, with five production lines using automatic bottling systems, and one traditional line for filling non-standard bottles (e.g. I litre bottles sent to the Soviet Union) manually. The scale of production for foreign and domestic markets was proved by a wide range of alcohols produced: pure vodkas, flavoured vodkas, bottled spirit, and methylated spirit. The 'Polmos' in Łódź was considered to be the best in Poland (Fig. 2, 3).

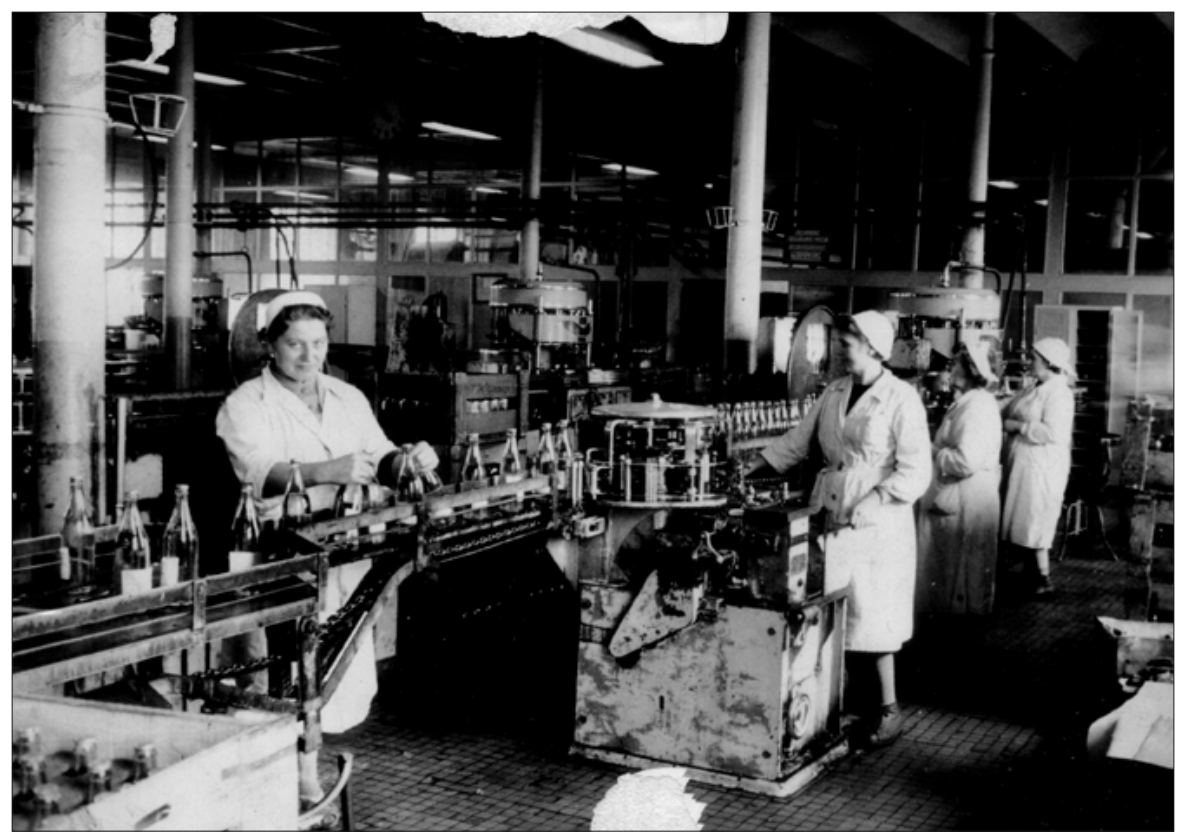

Fig. 2. A bottling line, a private photograph; donated by M. Kołodziejczyk; as published in: Karpińska, Krupa-Ławrynowicz, Ławrynowicz 2018. 
In the 1980s, the production process was further improved through mechanisation. Lifts were installed to distribute the products between floors, electric pallet trucks were introduced, and the bottling machines were exchanged.

However, during the economic transformation, the Monopoly in Łódź encountered financial problems. In 1991, it became a state company operating based on free market principles and not as part of the state monopoly as before. A decision was made to build a factory shop and a floor for the production of cream liqueurs. These activities, however, did

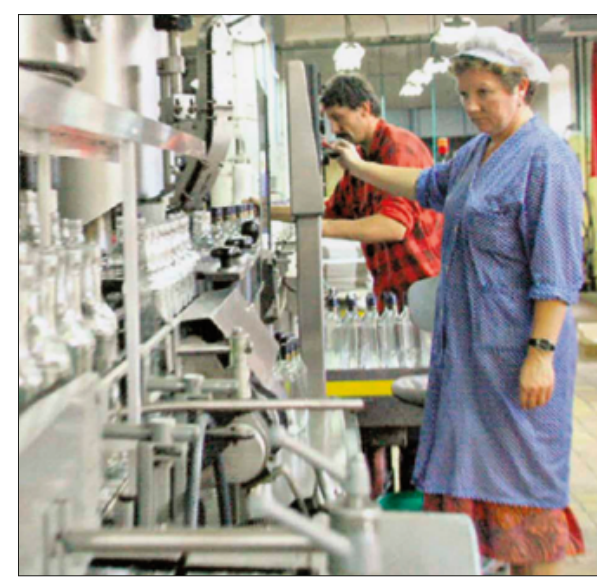

Fig. 3. A production line, a photograph from the 1990s; donated by M. Gabara; as published in: Karpińska, Krupa-Ławrynowicz, Ławrynowicz 2018. not improve the company's financial situation. The profits fell, and the business sustained more and more losses, as a result of which, in 1996, a special administrator was appointed for the company. There were attempts to find new markets by exporting Columbus and Szekspir vodkas to the USA and Canada. Another idea to save the company was to reduce production costs and focus on its most profitable range. However, none of these attempts was successful.

In April 2007, production was stopped, and a few months later, the last stocks from Polmos's storehouses were sold in the manufacturer's branded outlet at the corner of Kopcińskiego and Piłsudskiego Streets.

In 20I3, the property, being the third largest factory complex in Łódź (after the weaving plants of Karol Scheibler and Izrael Poznański), covering the area of nearly 20,000 square metres, was bought by a Łódź developer - the Virako company. In the spring of 20I4, the new owner announced that the former Monopoly would be called MONOpOLIs, and that it would become a space friendly towards cultural initiatives and a home for creative industries. The author of the visual identity and the logo of MONOpOLIs is a famous designer Janusz Kaniewski, while the name refers to the Greek word polis and can be understood as 'a city within a city', with the first part serving as a reminder of the industrial past of the place.

Krzysztof Witkowski, president of Virako and administrator of the space in its new form, emphasises that the new chapter in the biography of this place will combine modern functions with the historical fabric. 


\section{Research - Strategy and Effects}

The activities performed as part of the Monopol Wódczany w Eodzi. Miejsce i ludzie (Vodka Monopoly Plant in Eódź. The Place and People) project employed research methods and tools of ethnologists, cultural anthropologists and archaeologists.

The interviews conducted by ethnologists were based on the assumptions of in-depth interviews (Lofland et al. 2009: 4I; Charmaz 2009: 39-5I). One of the characteristics of in-depth interviews, as a research technique, is their limited interrogation area, however, they are intensive and explore the issue through thematically-oriented and focused questions. In the case of the project described, the questions concerned work in the factory, the way work organised the everyday life of workers and their families (i.e. our interviewees), and how events from the private life fit into the life of the factory.

Questions interviewees are asked during in-depth interviews are open-ended questions, expecting detailed and exhaustive descriptions, and particularly stories. Questions with such structural and pragmatic properties were not without reason called by Jerzy Giedymin questions demanding a narrative (Giedymin 1964: 16). On account of the above, the interview itself can be called a narrative interview in a broad sense, without any direct references to the narrowing concept of Fritz Schütze (Schütze 20I2; cf. Kaźmierska 1997; 2004; Rokuszewska-Pawełek 2002: 45-70).

Consequently, we recognised narratives as significant elements when recreating human experiences, allowing to reconstruct space and to help reach the 'time and place of the occurrence of a fact that had an effect on us (our interviewees - A.K.L.'s note)' (Halbwachs 2008: 137).

The eighteen stories we collected formed a meganarrative with a multitude of heroes/voices ${ }^{4}$. In a way, each of the narrators added their fragment of the story and filled it in with personal contents; when talking about the factory in their own way, each emphasised different dimensions of their biographical experience. The meganarrative of Łódzkie Zakłady Przemysłu Spirytusowego 'Polmos' consists of stories that concern, for example, the history of the factory - the official one and the remembered one; biographies of workers - circumstances of getting the job, career path, combining private life with professional life; the factory space and its organisation; production and technology - the formulas used for production; products and advertising; the rhythm and

4 The publication Monopol Wódczany $w$ Łodzi. Miejsce opowiedziane includes extensive citations from the ethnographic interviews conducted (Karpińska, Krupa-Ławrynowicz, Ławrynowicz 2018). 
organisation of work - responsibilities connected with the job, bonuses, promotions, raises, punishments, and dismissals; social conditions - healthcare, company vacation centres; relationships between workers - joint celebrations of name days and holidays, mushroom picking trips, ways of smuggling vodka outside the factory; but also liquidation of the factory (Fig. 4).

In the project described, the archaeologists' task was not to carry out archaeological and architectural research of the post-factory complex, but only to inventory the artefacts connected with its past. Thus, the artefacts were not obtained through excavations but through an organised collection of the socalled mementoes provided by former workers of Polmos, members of their families, and citizens of Łódź. The idea behind the collection was connected with the plans to open a small museum in the MONopolis complex, devoted to the former Zakłady Przemysłu Spirytusowego.

Nearly all the people who shared their mementoes with us later became our interviewees. We treated the artefacts handed over or lent as tangible relics of the contemporary past and, just like in the case of classical portable artefacts, we classified and inventoried them. Each of the two hundred and thirty-six ob-

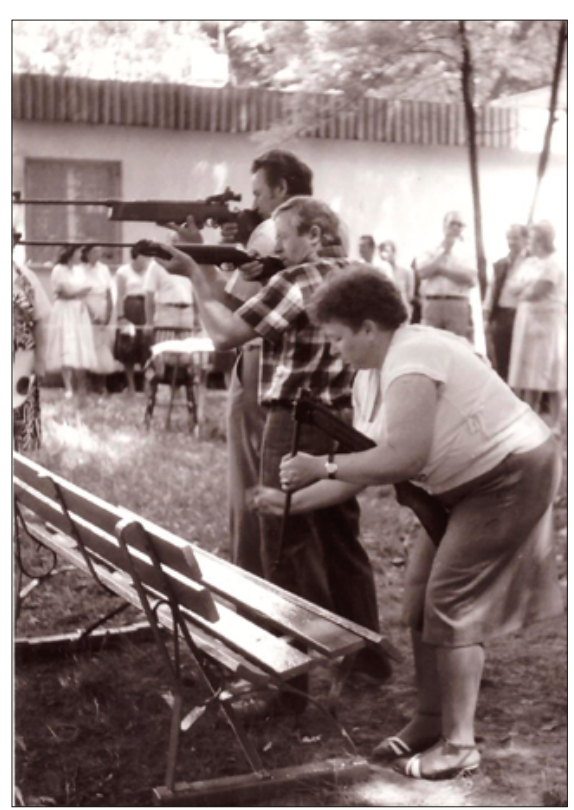

Fig. 4. A shooting contest in Tworzyjanki; a private photograph; donated by K. Sakwińska; as published in: Karpińska, Krupa-Ławrynowicz, Ławrynowicz 2018. jects received a label with an inventory number and brief information about the artefact and its owner.

We divided the collection into four categories: items (bottles, glasses etc.), photographs (showing the former factory, its staff at work and after hours, e.g. during sports events, on holiday, and during official and private meetings), private and official documents (identity cards, diplomas, memoirs, certificates, public notices, letters to management, internal economic analyses), and trade and press documents (advertising folders and leaflets, product catalogues, articles from trade and everyday press (Fig. 5, 6, 7, 8).

The objects collected form an interesting example of tangible culture connected with the everyday work in a factory as well as the social and private life regulated by the work. We 


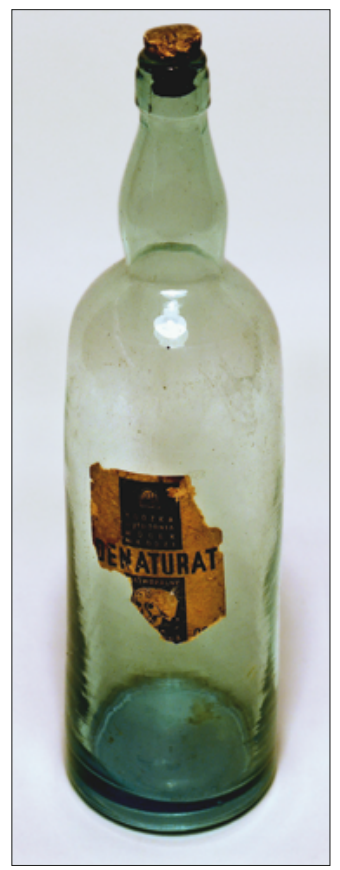

Fig. 5. A half a litre bottle with a fragment of a label with a sign: "EÓDZKA WYTWÓRNIA WÓDEK w ŁODZI" ("Łódź Vodka Distillery in Łódź") and "DEnaturat, [ $\mathrm{E}$ ] ATWopalny" ("Metylated Spirit, flammable"), "[TrUCI]ZnA" ("Poison"), "0.5 [1] from the 1930s-1950s; donated by: J. Gołębiowska; as published in: Karpińska, Krupa-Ławrynowicz, Ławrynowicz 2018.

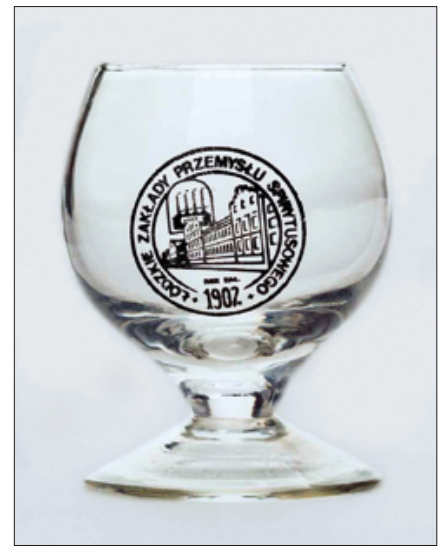

Fig. 6. A promotional vodka glass with the trademark "Łódzkie Zakłady Przemysłu Spirytusowego. Rok zał. 1902"; donated by A. Jędrzejczak and Z. Banaszczyk; as published in: Karpińska, Krupa-Ławrynowicz, Ławrynowicz 2018.

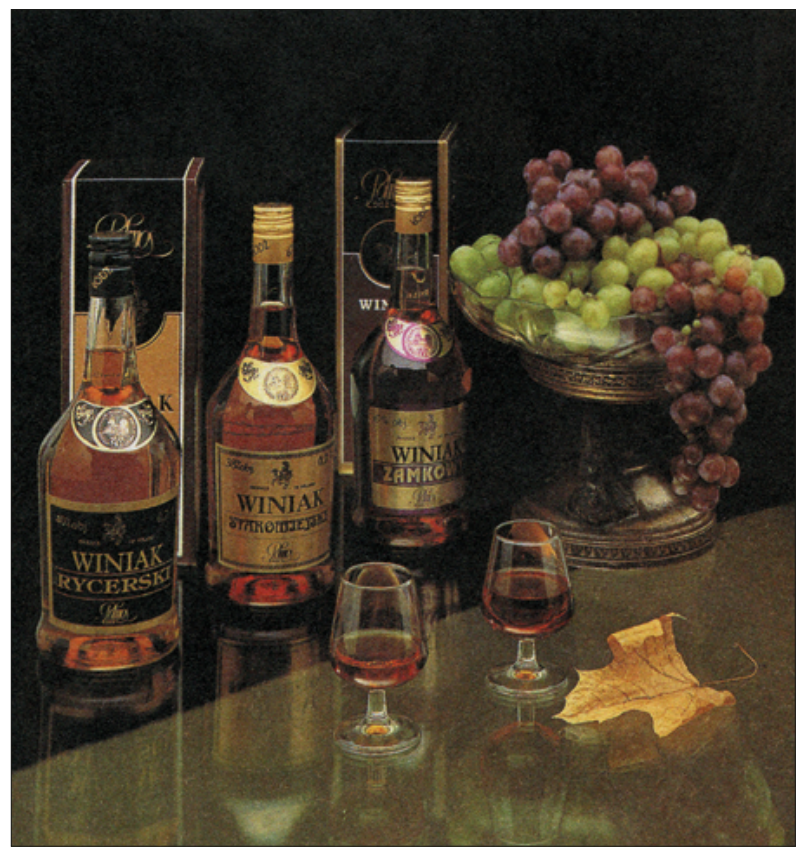

Fig. 7. Pages from an advertising brochure of Łódź Polmos from the 1990s; donated by W. Ossowski; as published in: Karpińska, Krupa-Ławrynowicz, Ławrynowicz 2018. 
treated them as sources of knowledge, and certain evidence forming a basis for drawing conclusions about culture, morality and social space of a given time and place. Despite the relatively short chronology of the objects as portable artefacts, many of them are unique as, paradoxically, they have small material and collector's value (except for older bottles and labels). Had it not been for the media and sentimental context that accompanied our collection, most of these object would have sooner or later become waste (cf. Krupa-Ławrynowicz, Ławrynowicz 20I2).

To us, the inventory of historical objects, made in a way typical of excavation research, was a kind of a manifesto, through which we wanted to show that the contemporary past is also an area explored by archaeology, which is referred to as archaeology of the contemporary past (Archaeologies of the Contemporary Past... 200I; Zalewska 2016). In the case of the artefacts from the former Monopol Wódczany we followed the same procedure for classifying, describing and interpreting we use with regard to artefacts of tangible culture studied by historical archaeology (Kajzer 1996: 206-250). What makes them different is the possibility of referring them to a specific group of people or individuals. They become parts of someone's biography and, thanks to the stories of their owners, they also receive their own biographies (cf. Kobiałka 20I5; 20I7).

In one of the cases, the artefact directed us towards the biographies of its owners. In 20I8, during repair work on the roof of the filter house of the former Łódź Monopoly, a corked half a litre vodka bottle was found, with a piece of paper inside covered with text written with a copying pencil. At first, the text seemed illegible,

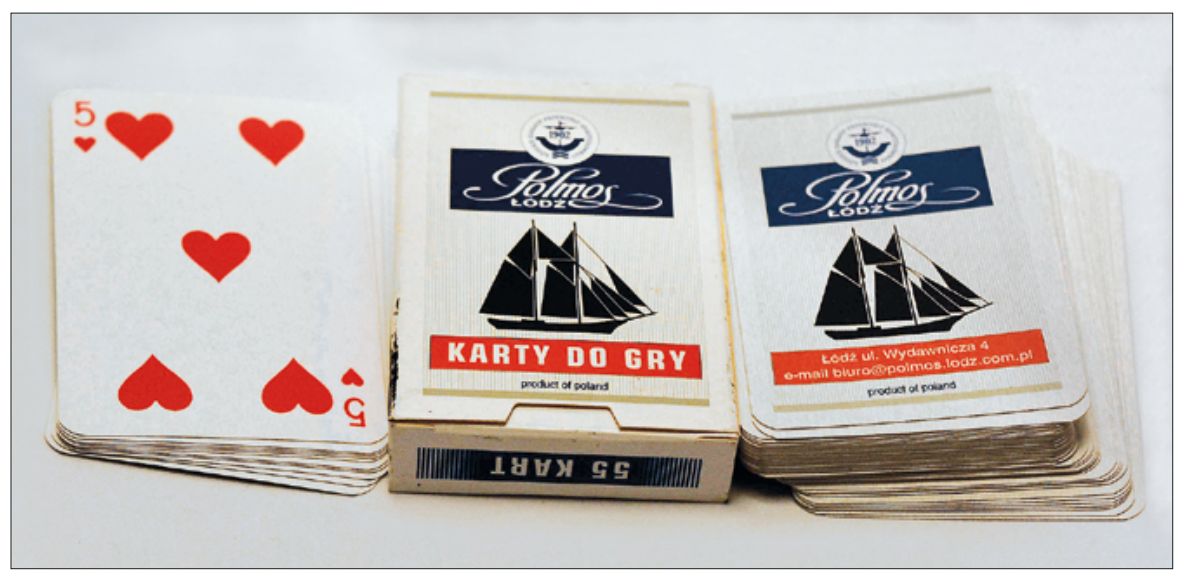

Fig. 8. An advertising box with a pack of cards with trademarks "Polmos Łódź" and "Łódzkie Zakłady Przemysłu Spirytusowego. 1902”; donated by A. Jędrzejczak and Z. Banaszczyk; as published in: Karpińska, Krupa-Ławrynowicz, Ławrynowicz 2018. 
but thanks to the help of Doctor Adam Sitarek from the Institute of History of the University of Łódź, it was possible to read it (a simplified version):

This letter was written down by: two painters, one from Kalisz, and one from Łódź. The one from Kalisz is Stanisław Prusiewicz. The one from Łódź is Józef Pruskalski. Łódź, $26^{\text {th }}$ November 1929 .

I, Stanisław Prusiewicz, the former defender of Warsaw in 1920. This paper is for remembrance. We are writing during work, it is $8 \mathrm{am}$, the day is Tuesday. We hereby sign: St. Prusiewicz, Józef Pruskalski. Please give this paper to painters. Born in the years: Stanisław Prusiewicz 1902, Józef Pruskalski 1907.

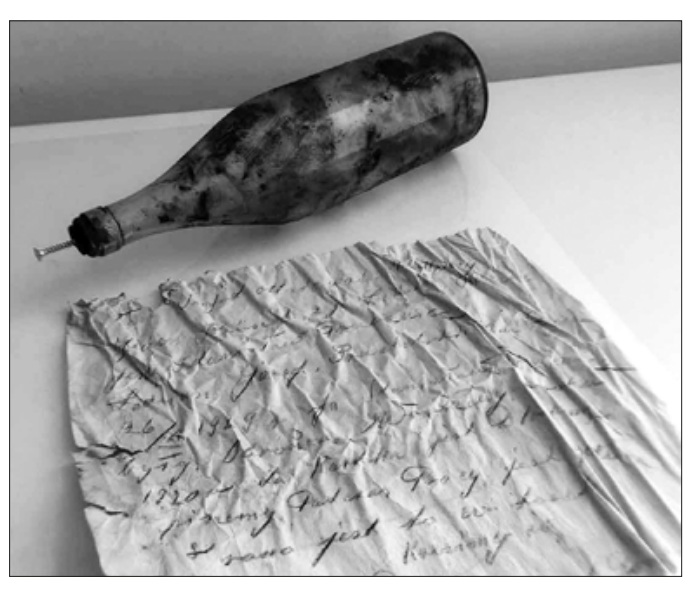

Fig. 9. A bottle with a letter discovered in 2018 during repair work on the roof of the filter house of the former Łódź Monopol; as published in: Karpińska, Krupa-Ławrynowicz, Ławrynowicz 2018.
The note is a letter for which a half a litre vodka bottle became a time capsule. On Tuesday, November 29, 1929, at 8 am, two painters: Stanisław Prusiewicz (b. February or May 1902) and Józef Pruskalski (b. April 1907), who were painting the internal, wooden side of the roof, wrote a letter to their colleagues (painters) from the future. It is worth noting that this was so important to twenty-fiveyear-old Stanisław and twenty-year-old Józef that they provided their full names, dates of birth, and places of birth (the

first one was from Kalisz, and the other one from Łódź). Stanisław also emphasised that he had defended Warsaw during the Polish-Soviet War in 1920. After ninety years, the men's wish to be remembered came true more fully than they had expected: their letter did not only reach painters, but it was also published in the Łódź press (Fig. 9).

While working on the materials collected, we used archives, the press, and the Internet. This consisted in surveys of available archival sources and the existing studies and documents, both scientific and parascientific. We identified and analysed materials from a hundred archival units (mostly the collections of the State Archive in Łódź and the City of Łódź Archive) connected with the operation of the 
factory (including architectural designs, financial statements, registers of invention designs, organisation charts, price lists, and commemorative books).

The survey also covered iconographic materials published online (ninety archival and contemporary photographs were collected and catalogued) and press releases available online and in library collections (forty-seven texts were collected and catalogued).

Moreover, the survey involved analysis of national and foreign museum projects and exhibitions, the topics of which were connected with the artefacts presented or the space used/converted and referred to the unique character of the factory we studied, which was why they could offer some practical hints about the ways of using the materials obtained during the project ${ }^{5}$.

However, we mostly learnt about the history of the Łódź Monopoly from our interviewees. We were able to visit the past of a place, which had not been well explored before, thanks to the people who agreed to share their memories, impressive trade knowledge, personal archives and mementoes. Naturally, such reconstruction of the past of a place is incomplete. One of the reasons for this is the nature of the ethnographic material, the aim of which is not to show 'everything. The memories collected are 'stories from memory', which - as anthropological researchers know perfectly well - implicates selectivity, and so fragmentariness. From the memory storehouse one can only obtain the best preserved fragments of a sometimes non-existent whole. In the narratives we used, the factory space was limited to one building, and sometimes even to the production hall. These are spaces the authors are familiar with thanks to their direct, everyday experience. Such selectivity of memory concerns not only the topography of the factory complex, but also events and people. Thus, let me repeat this, such reconstruction expresses individual and collective experiences and talks about a reality full of people, their biographies, and ideas, determined by events and actions.

\section{A Place - New Urban Narrative}

Sharon Zukin claims that a city promotes itself by skilfully modelling its material dimension, and in a post-industrial city revitalised spaces serve the role of its 'most important visual representations' (Zukin 1995: I6). The new administrators of the former Monopol Wódczany seem to understand this well. They

5 Transcripts of the ethnographic interviews, the artefacts collected (and their catalogue), and the results of surveys were provided to Virako Sp. z o.o. The part of materials the authors deemed most representative was included in the already quoted work on Monopol Wódczany in Łódź. 
carefully select and pick the contents of this projection ${ }^{6}$. They implement their plans consistently and successfully, which is reported in the press, and which is confirmed by my observations (as a citizen of Łódź).

Even before the revitalisation, exhibitions, concerts, film screenings, photo sessions, and fashion shows were organised in the former factory. However, this temporary event space is only a fragment of the metamorphosis. MONOPOLIS wants to combine different fields of activity. Apart from the office part, there will be space for cultural events, leisure activities, and relaxation. The cultural and recreational offer will include music events, exhibitions and theatre shows on two stages: an outdoor stage and a stage in the former spirit storehouse, as well as restaurants in the former laboratory of flavoured vodkas. An important element of the offer will be a museum devoted to the workers of the former Polmos and technologies of vodka production (www.monopolis.pl). In their communications, the owners emphasise that one of the chief assets of the place will be its post-industrial architecture or post-factory character (Fig. Io).

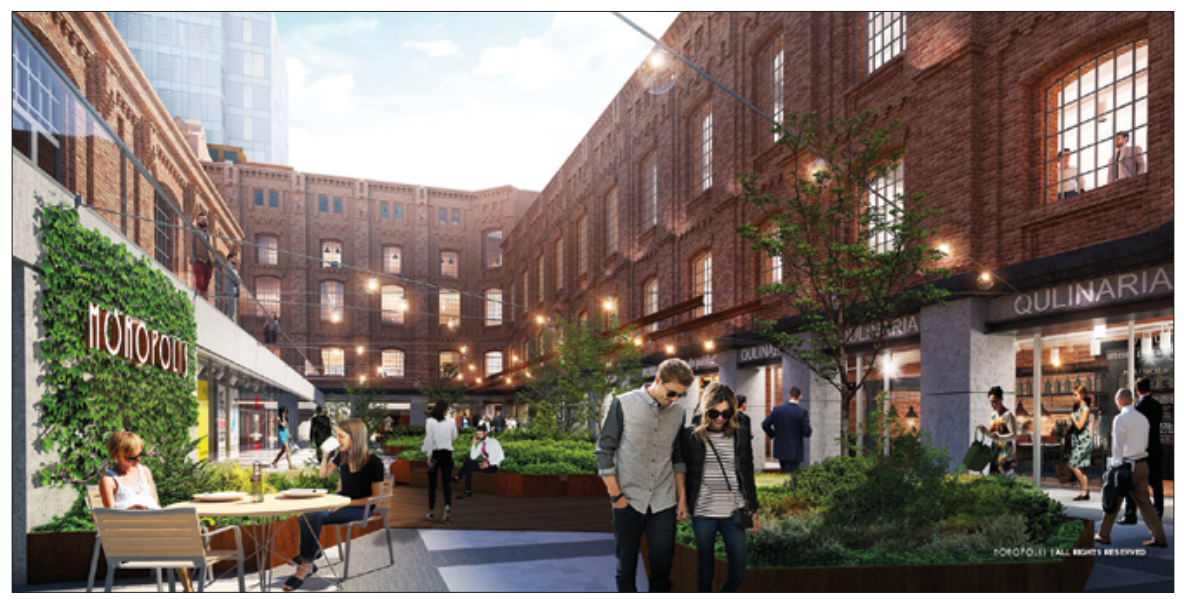

Fig. 10. A promotional photograph of MONOPOLIs; as published on http://monopolis.pl.

The researchers, who in this case are burdened with involvement in the urban project described, can now only carefully and critically observe the transformation process.

Today, only a few people would question the statement that space is not only created by architects, urban planners, and investors, but also by ways in

6 Thus, somewhere in the margin, an old Lefebvre's question emerges: 'Who does the city belong to?' or, in other words, 'What has the right to be included in the dominant image of the city?' (Zukin 1995: II). 
which it is re-constituted or transformed by the 'everyday practice', meaning the experiences and activities of entities that exist in a given space and use it. From this perspective, the MONOPOLIs space is only a potential space; it is a new urban narrative. When talking about urban narratives, we have to consider three notions: place, memory, and activity (Michałowska 20I4: 249).

Places are not only connected with a spatial factor, but also with an identity-related factor (because a 'place', according to the phenomenological interpretation, is a consequence of the sense of belonging). Places are created by the work of memory (it can be said that they consider the temporal dimension - continuity or its end), while activity triggers a narrative acting as an intermediary between places and memory. This is of significance to architects and investors who create their own narratives and take into consideration the narratives of places; it is also significant to people whose lives made narratives using the urban fabric. As Robert A. Beaurogard wrote:

\begin{abstract}
All sites exist first as places. Before places become objects of urban planning and design, they exist in personal experience, hearsay, and collective memories. Standing between planners and designers and the sites on which they hope to act are socially embedded narratives. And, while these place narratives can be ignored, they cannot be wholly erased. Places are never empty (Beaurogard 2005: 39).
\end{abstract}

It is thus worth remembering about the obligation to include constant de-re-construction processes in different plans and on different levels, as Anna Zeidler-Janiszewska emphasises. The city is a residence of past and future generations'. Their 'voices should be present and heard just like ours' (ZeidlerJaniszewska 1997: 8). Urban narratives lead to the past, shape the present, and design the future at the same time, thanks to different records of memory and experiences occupying the same space simultaneously.

'Voices' or, in other words, 'urban narratives' are factors giving meaning to space. People give meaning to the space they live in thanks to their ideas and actions they take. Narratives reveal the significance of space, hierarchising its value in individual and social terms. They are also action-related as they are

7 I leave aside the tempting and quite obvious with regard to the issue in question category of palimpsest, which became a metaphor of a postmodern city as an effect of Ricoeur's hermeneutics of trace (Huyssen 2003; Karpińska 2004; Rewers 2005; Turner 20IO). It is popular among architects and writers, but also cultural anthropologists and archaeologists who want to express the multilayer structure, sensuality and historic nature of the urban fabric. Perceiving the city as a palimpsest allows to see the rhythm of history, construction and destruction, and accumulation of one culture over the other. The idea of a palimpsest consists in combining all layers, at the same time drawing attention to their temporariness. 
expressed through the relationships between objects and space, and the 'participation of bodies in the discourse' (de Certeau 2008: II6), meaning activities and all moves made by participants in the urban space.

Will the narratives of former workers of Zakłady Przemysłu Spirytusowego Polmos function along new narratives, and if yes, then in what configuration? This question is yet to be answered.

However, this discussion leads to another observation which - even though it appears at the end - is constitutive for the city as a character. It concerns the acknowledgement that the city is, by nature, never finished. Here is what Tadeusz Sławek wrote about it:

\footnotetext{
What happens in the city, what is built in the city (the city, in its present (de)form(ity), strikes its inhabitants with the emergence of new structures, repairs, and demolitions, which are signals of anonymous powers, for which the city is a perfect environment; we could even go as far as to say that - using Plato's language - the city is a home for these anonymous powers), and what requires a specific de/re/construction of perspective (Sławek 20IO: 20).
}

The city is only on its way to itself, not ready, and its seemingly most lasting structures are, in fact, most fragile and misleading, while each interference in the city fabric is connected with uncertainty that accompanies any shift in the significance of a place which we cannot fully predict.

\section{Bibliography}

Archaeologies of the Contemporary Past (2001), V. Buchli, G. Lucas (ed.), Routledge, London-New York.

Beaurogard R.A. (2005), From Place to Site: Negotiating Narrative Complexity, [in:]

A Kahn, C. Burns (ed.), Site Matters, Routledge, New York, p. 39-58.

Certeau de M. (2008), Wynaleźć codzienność. Sztuki dziatania, Wydawnictwo Uniwersytetu Jagiellońskiego, Kraków.

Charmaz K. (2009), Teoria ugruntowana. Praktyczny przewodnik po analizie jakościowej, Wydawnictwo Naukowe PWN, Warszawa.

Giedymin J. (1964), Problemy, zatożenia, rozstrzygnięcia. Studia nad logicznymi podstawami nauk spotecznych, Państwowe Wydawnictwo Naukowe Oddział w Poznaniu, Poznań.

Halbwachs M. (2008), Spoteczne ramy pamięci, Wydawnictwo Naukowe PWN, Warszawa. Huyssen A. (2003), Present Past. Urban Palimpsest and the Politics of Memory, Stanford University, Stanford. 
Joint ICOMOS - TICCIH Principles for the Conservation of Industrial Heritage Sites, Structures, Areas and Landscapes (2011), https://www.icomos.org/Paris2011/ GA2011_ICOMOS_TICCIH_joint_principles_EN_FR_final_20120110.pdf. Kajzer L. (1996), Wstęp do archeologii historycznej, Wydawnictwo Uniwersytetu Łódzkiego, Łódź.

Karpińska G.E. (2004), Miasto wymazywane: historia tódzkiego przypadku, "Studia Etnologiczne i Antropologiczne”, 8, p. 165-178.

Karpińska G.E., Krupa-Ławrynowicz A., Ławrynowicz O. (2018), Monopol Wódczany $w$ Łodzi. Miejsce opowiedziane, Instytut Archeologii UŁ; Virako Sp. z o.o., Łódź.

Kaźmierska K. (1997), Wywiad narracyjny - technika i pojęcia analityczne, [in:]

M. Czyżewski, A. Piotrowski, A. Rokuszewska-Pawełek (ed.), Biografia a tożsamość narodowa, Katedra Socjologii Kultury Uniwersytetu Łódzkiego, Łódź, p. 35-44.

Kaźmierska K. (2004), Wywiad narracyjny jako jedna z metod $w$ badaniach biograficznych, "Przegląd Socjologiczny", 53, p. 71-96.

Kobiałka D. (2015), Biografia rzeczy jako sposób interpretowania roli i znaczenia dziedzictwa, [in:] M. Kępski (ed.), Z rzeka w tle. Biografia Śluzy Katedralnej / Framed by the River. The Biography of the Cathedral Lock, Centrum Turystyki Kulturowej Trakt, Poznań, p. 44-49.

Kobiałka D. (2017), Kufer peten wspomnień: (auto)biograficzne podejście do dziedzictwa, "Acta Universitatis Lodziensis. Folia Archaeologica", 32, p. 191-213, https://doi. org/10.18778/0208-6034.32.08

Kronenberg M. (2009), Rozwój miejskiej przestrzeni turystycznej opartej na dziedzictwie przemystowym, "Prace Geograficzne”, 121, p. 191-198.

Krupa-Ławrynowicz A., Ławrynowicz O. (2012), Wyrzucana codzienność. Antropolog $z$ archeologiem rozmawiają o śmieciach, [in:] M. Sztandara (ed.), Brud. Idee - dylematy - sprawy, Wydawnictwo Uniwersytetu Opolskiego, Opole, p. 139-154.

Lofland J., Snow D.A., Anderson L., Lofland L.H. (2009), Analiza uktadów spotecznych. Przewodnik metodologiczny po badaniach jakościowych, Wydawnictwo Naukowe Scholar, Warszawa.

Michałowska M. (2014), Narracje, [in:] E. Rewers (ed.), Kulturowe studia miejskie. Wprowadzenie, Narodowe Centrum Kultury, Warszawa, p. 223-262.

Rewers E. (2005), Post-polis. Wstęp do filozofii ponowoczesnego miasta, Universitas, Kraków. Rokuszewska-Pawełek A. (2002), Chaos i przymus. Trajektorie wojenne Polaków-analiza biograficzna, Wydawnictwo Uniwersytetu Łódzkiego, Łódź.

Schütze F. (2012), Analiza biograficzna ugruntowana empirycznie w autobiograficznym wywiadzie narracyjnym. Jak analizować autobiograficzne wywiady narracyjne, [in:] K. Kaźmierska (ed.), Metoda biograficzna w socjologii. Antologia tekstów, Nomos, Kraków, p. 141-278. 
Sławek T. (2010), Miasto. Próba zrozumienia, [in:] E. Rewers (ed.), Miasto w sztuce - sztuka miasta, Universitas, Kraków, p. 17-70.

Słodczyk J. (2003), Przestrzeń miasta i jej przeobrażenia, Wydawnictwo Uniwersytetu Opolskiego, Opole.

Stefański K. (2016), Narodziny miasta. Architektura i rozwój przestrzenny Łodzi do 1914 roku, Wydawnictwo Jacek Kusiński, Łódź.

Turner V. (2010), Proces rytualny. Struktura i antystruktura, Państwowy Instytut Wydawniczy, Warszawa.

Walczak B.M. (2014), Opracowanie naukowo-historyczne wraz z ocena wartości kulturowych zespotu poprzemystowego zaktadów przemystu spirytusowego „Monopol Wódczany" w Łodzi, Łódź (mps w arch. Virako Sp. z o.o.).

Zalewska A.I. (2016), Archeologia czasów wspótczesnych w Polsce. Tu i teraz, [in:] A.I. Zalewska (ed.), Archeologia wspótczesności. Pierwszy Kongres Archeologii Polskiej, vol. I, Stowarzyszenie Naukowe Archeologów Polskich, Warszawa, p. 21-39.

Zeidler-Janiszewska A. (1997), Stowo wstępne, [in:] A. Zeidler-Janiszewska (ed.), Pisanie miasta - czytanie miasta, Wydawnictwo Fundacji Humaniora, Poznań, p. 7-10.

Zukin S. (1995), The Cultures of Cities, Blackwell, Oxford.

http://baedekerlodz.blogspot.com (access 25 V 2017).

http://www.monopolis.pl (access 10 IX 2019).

\section{Summary}

In the Factory, in Łódź, in the City. Reconstructing the Industrial Past of a Place

The paper discusses an interdisciplinary research project (2014-2016) concerning the industrial heritage of Łódź, as exemplified by the former Monopol Wódczany, which is today converted for the purposes of new, cultural and service functions. The aim of ethnographic and archaeological activities was to collect oral histories and artefacts, which not only documented the history of the factory, but also presented the professional biographies of its workers, meaning people whose lives had been intertwined with the activity of the company. Thanks to such a research assumption, the researchers were able to reconstruct the industrial past of the place based on memories, artefacts collected, and archive surveys. The Author describes the idea behind the project, its methodology and results, using the notions of industrial heritage and urban narratives as the analytical context.

Keywords: industrial heritage, ethnographic research, archaeological research, urban narratives, Łódź, Monopol Wódczany in Łódź, Monopolis 
In the Factory, in Łódź, in the City. Reconstructing the Industrial Past of a Place

\section{Streszczenie}

\section{W fabryce, w Łodzi, w mieście. Rekonstruowanie przemysłowej przeszłości miejsca}

W artykule omówiony zostaje interdyscyplinarny projekt badawczy (20I4-20I6) dotyczący dziedzictwa przemysłowego Łodzi, na przykładzie dawnego Monopolu Wódczanego, dzisiaj adaptowanego do nowych funkcji kulturalno-usługowych. Celem badań etnograficznych i archeologicznych było zebranie przekazów ustnych oraz artefaktów, nie tylko dokumentujących historię fabryki, lecz również przedstawiających zawodowe biografie pracowników, czyli osób, których życie splecione było z działalnością przedsiębiorstwa. Dzięki takiemu założeniu, badaczom udało się zrekonstruować przemysłową przeszłość miejsca na podstawie wspomnień, zgromadzonych przedmiotów oraz kwerend archiwalnych. Autorka opisuje ideę, metodologię oraz rezultaty projektu, wykorzystując jako kontekst analityczny pojęcia dziedzictwa przemysłowego i miejskich narracji.

Słowa kluczowe: dziedzictwo przemysłowe, badania etnograficzne, badania archeologiczne, miejskie narracje, Łódź, Monopol Wódczany w Łodzi, Monopolis

\section{Aleksandra Krupa-Ławrynowicz}

University of Łódź, Institute of Ethnology and Cultural Anthropology

e-mail: aleksandra.lawrynowicz@uni.lodz.pl 